\title{
Isolation and Characterization of Drought Tolerant Bacteria from Rice Phyllosphere
}

\author{
D. Arun Kumar ${ }^{1}$, K.G. Sabarinathan ${ }^{2 *}$, R. Kannan ${ }^{2}$, D. Balachandar ${ }^{1}$ and M. Gomathy ${ }^{3}$ \\ ${ }^{1}$ Department of Agricultural Microbiology, Tamil Nadu Agricultural University, \\ Coimbatore - 641031, India \\ ${ }^{2}$ Department of Plant Pathology, AC \& RI, Killikulam, Vallanadu, Tuticorin-628252, India \\ ${ }^{3}$ Department of Soil Science and Agricultural chemistry, AC \& RI, Killikulam, Vallanadu, \\ Tuticorin - 628252, India \\ *Corresponding author
}

\begin{abstract}
A B S T R A C T
Tamil Nadu is one of the top rice production states in India. Southwest monsoon failure of recent years in Tamil Nadu hits with severe drought, especially in the regions of

\begin{tabular}{|l|}
\hline Ke y w or d s \\
Nootripattu and \\
Mattaikar, \\
Phyllosphere \\
\hline Article Info \\
\hline Accepted: \\
20 May 2019 \\
Available Online: \\
10 June 2019 \\
\hline
\end{tabular}
Ramanathapuram districts. The main objective of present study is to isolate drought tolerant bacteria from phyllosphere of drought tolerant rice varieties cultivated in paramakudi region. Rice phyllosphere constitutes the diversified microbial community. The phyllosphere bacteria were isolated in different media Nutrient agar, Tryptic soy agar, R2A agar, and King's B media from four drought tolerant rice varieties Anna R(4), PMK3, Nootripattu and Mattaikar. A total of 50 different bacterial isolates were purified and screened for abiotic stress tolerance such as drought stress at PEG6000 $(-0.15 \mathrm{MPa}$, $0.49 \mathrm{MPa},-0.73 \mathrm{MPa}$ and $-1.2 \mathrm{MPa}$ ), salt stress at $1.2 \mathrm{M} \mathrm{NaCl}$ and temperature stress at $50^{\circ} \mathrm{C}$. The isolates were named with series PB. The best 8 isolates PB3, P17, PB18, PB23, PB24, PB37, PB46 and PB50 was first biochemically characterized and screened for production of plant growth hormones IAA and $\mathrm{GA}_{3}$ at different PEG6000 stress. The result shows PB50 and PB46 has highest production of plant growth hormones and sustain drought stress. Future works are characterization of isolates for Plant growth promotion activities and application of isolates on rice for drought mitigation.
\end{abstract}

\section{Introduction}

Water is essential for all living organisms. A key challenge for plant growth is global water shortage, limiting crop yields already today in more than $70 \%$ of arable lands, and the drought limitations further gain in importance in the near future as agricultural activities expand to less fertile areas to satisfy growing demands for food. Moisture stress during the crop ontogeny has been one of the main constraints for sustainable rice productivity, especially in uplands (Hossain, 2014). Integrating microbes as component of agricultural system for enhanced drought tolerance in plants needs to be endorsed to 
boost sustainable crop production (Trivedi et al., 2017). The aerial habitat colonized by microbes is termed as Phyllosphere and the microorganisms are called as epiphytes. Most of the Phyllosphere microorganism occupies the surface area of leaves, flowers and fruits, and work has been focused mainly on Phyllosphere microbiology on leaves, a dominant aerial structure of plants. Bacteria are the dominant microbiome on leaf with the numbers averaging $10^{6}$ to $10^{7}$ cells $/ \mathrm{cm}^{2}$ of leaf (H. Andrews and F. Harris, 2000). Phyllosphere is an extreme and unstable habitat where it is exposed to different environmental factors, mainly high light, UV radiation, temperature and desiccation. It has the characteristics of oligotrophy limitation in carbon and nitrogen sources. It is reported that microorganism in Phyllosphere utilize the plant metabolites available on leaf surface such as soluble sugars, polyols, amino acids, amines and VOC (Bringel and Couée, 2015). Proline is the most abundant osmolytes produced in both eukaryotes and prokaryotes. Glutamate acts as precursor of proline, during stress condition bacteria utilize three enzyme mechanism glutamate kinase, glutamate-ysemialdehyde dehydrogenase and pyrroline-5carboxylate reductase for converting glutamate to proline (Sugiura and Kisumi, 1985). Proline slakes the drought stress by two strategies, one by acting as chemical chaperone which directly scavenges the reactive oxygen species generated during stress and other strategy by indirect mechanism, which activates signalling pathway and balances the cellular energy (Liang et al., 2013). Bacteria uses several strategies to protect from osmotic stress, they produce quaternary ammonium compounds like Glycine Betaine (GB), Choline and Proline betaine, which serves as osmoprotectant (Slama et al., 2015). GB and choline are a dominant osmoprotectant in bacteria followed by proline, they act as protein chaperons and stabilize the protein from denaturation during stress condition, it is proven that both the osmolytes stabilize the enzymatic activity of citrate synthase during thermal stress in E. coli strains (Caldas et al., 1999). Though Choline and GB acts as osmoprotectant, Choline is the precursor of glycine betaine. The homeostasis between choline and GB has been studied in Pseudomonas aeruginosa, during osmotic stress certain level of choline is oxidized to GB using enzymescholine oxidase and betaine aldehyde dehydrogenase (Fitzsimmons et al., 2012). In This present study we have isolated drought tolerant bacterial isolates from four drought tolerant rice varieties. The ability of drought tolerant bacterial isolates to produce phytohormone was assessed.

\section{Materials and Methods}

\section{Sample collection site}

We studied four rice drought varieties maintained in the fields of the Agricultural research station, Paramkudi (9'33'01.8' N $78^{\circ} 34^{\prime} 53.7^{\prime \prime} \mathrm{E}$ ) with soil $\mathrm{pH} 9.3 \pm 0.2$ and EC $0.177 \pm 0.008 \mathrm{dsm}^{-1}$, which is considered to be an alkaline soil. Temperature was recorded to be $40^{\circ} \mathrm{C}$ during collection. The varieties are Mattaikar, Nootripattu, Anna R (4) and PMK3, which are at the vegetative phase. The $4^{\text {th }}$ and $5^{\text {th }}$ leaves of main tillers were collected randomly from the field in the morning using sterile plastic bags and was transported to the laboratory in an icebox and analysed immediately.

\section{Isolation of phyllosphere bacteria}

The leaf samples were washed using sterile water in order to isolate putative bacteria colonized on the leaf surface. To isolate bacterial population on the adaxial and abaxial leaf surface, Both the sides of leaf were imprinted on different agar media, 
Nutrient agar, Tryptic soy agar, R2A agar, and King's B media, Individual leaf of size 5 $\mathrm{cm}$ each was placed on agar media and the imprint was done by pressing the leaf sample using a sterile glass rod (Yadav et al., 2010). The plates were incubated for $24 \mathrm{hr}$ at $30^{\circ} \mathrm{C}$ and the morphologically different colonies were picked and purified in the respective agar plates and final purification was done tryptic soy agar. Finally, 50 isolates were obtained and screened for abiotic tolerance. The isolates were named from PB1 to PB50. Isolate PB1 to PB21 belongs the Anna $\mathrm{R}(4)$; isolates $\mathrm{PB} 22$ to $\mathrm{PB} 35$ belongs to PMK3; isolates PB35 to PB42 belongs Nootripattu and isolates PB43 to PB50 belongs Mattaikar. Then bacterial isolates were preserved in $50 \%$ glycerol stock at $-20^{\circ} \mathrm{C}$.

\section{Screening of bacterial isolates for abiotic stress}

All the isolates were subjected to check their ability to tolerate different drought stresses such as high temperature $\left(50^{\circ} \mathrm{C}\right)$, salinity $(1.2 \mathrm{M})$, and drought $(-0.15,-0.49,-0.73$ and -1.2 MPa) using tryptone soy broth (TSB). The Initial inoculum for screening the isolates were grown in TSB broth for $6 \mathrm{~h}$ to $7 \mathrm{~h}$ and the final bacterial population was adjusted to same optical density (0.1). The growth of all isolates in stress conditions were recorded using spectrophotometer at $600 \mathrm{~nm}$ with sterile medium as blank and this was done in triplicate. Bacterial isolates with OD 0.5 and more are considered as stress tolerant bacteria (Praveen Kumar et al., 2014)

\section{High temperature tolerance}

Ten $\mathrm{mL}$ of TSB was dispensed into $30 \mathrm{~mL}$ test tubes and autoclaved. Then the sterile broth was inoculated with $0.1 \mathrm{ml}$ uniform cell density (0.1) of exponentially grown fresh bacterial cultures and tubes were incubated at $50^{\circ} \mathrm{C}$ on a shaker $(120 \mathrm{rpm})$ for $24 \mathrm{~h}$ and OD were recorded at $600 \mathrm{~nm}$.

\section{Drought tolerance}

For screening the drought tolerant isolates, a known quantity of TSB medium amended with four different concentration of polyethylene glycol-6000 was used. - 0.15 $\mathrm{MPa}$ [110 gm PEG per 1L media (w/v)], $0.49 \mathrm{MPa}$ [210 gm PEG per 1L media (w/v)], - 0.73 [260 gm PEG per 1L media (w/v)] MPa and - 1.2 MPa [326 gm PEG per $1 \mathrm{~L}$ media $(w / v)$ ] was dissolved by heating in a microwave oven, and then the final volume was made up to 1L with PEG amended medium(Michel and Kaufmann, 1973). The liquid medium was dispensed in $30 \mathrm{~mL}$ capacity test tubes and autoclaved. Fresh cultures of test strains grown for $6 \mathrm{~h}$ to $7 \mathrm{~h}$ on a shaker incubator, population were adjusted to OD 0.1 and used as initial inoculum. The inoculated tubes were incubated at $28^{\circ} \mathrm{C}$ for $24 \mathrm{~h}$ on a shaker $(120 \mathrm{rpm})$ and OD was recorded

\section{Salinity tolerance}

To the $100 \mathrm{ml}$ conical flask $30 \mathrm{~mL}$ of TSB amended with $1.2 \mathrm{M} \mathrm{NaCl}[70 \mathrm{gm}$ of $\mathrm{NaCl}$ in 1L of TSB broth (w/v)] was dispensed and autoclaved. Fresh cultures of test isolates grown for $6 \mathrm{~h}$ to $7 \mathrm{~h}$ on a shaker incubator were adjusted to the OD of 0.1 and used as initial inoculum. The inoculated tubes were incubated at $28^{\circ} \mathrm{C}$ for $24 \mathrm{~h}$ on shaker $(120$ rpm) and OD was recorded.

\section{Biochemical characterization}

Biochemical characterization test such as indole production, Methyl red test, VogusProskauer test, Citrate utilization test, Amylase test, Catalase test, Urease test, Pectinase test, Cellulase test, Gram staining, $3 \% \mathrm{KOH}$ test, cell shape, Hydrogen sulphide production test and Carbon assimilation test was performed according to (Thayer and Murray, 1977). 
For all the biochemical tests $24 \mathrm{~h}$ grown bacterial isolates were used and results were denoted in positive and negative.

\section{Bacterial diversity analysis}

The positive and negative data from biochemical characterization was represented in binary data with positive as one and negative as zero. With the binary data obtained, dendrogram was developed using NTSYS software(Rohlf, 1988) and bootstrap value was generated using $\mathrm{R}$ programming.

\section{Estimation of IAA production at different PEG 6000 concentration}

The bacterial isolates were grown in TSB broth for $24 \mathrm{~h}$. Then isolates were transferred to $10 \mathrm{ml}$ of TSB broth without and with PEG at three different concentration $(-0.15 \mathrm{MPa}$, $0.49 \mathrm{MPa}$ and $-0.73 \mathrm{MPa}$ ) amended with $0.1 \%$ of Tryptophan in triplicate. Then incubated for $48 \mathrm{~h}$ in a shaker at $28^{\circ} \mathrm{C}(120$ rpm). The IAA production was determined using the Salkowski method (Rahman et al., 2010). After $48 \mathrm{~h}$ of growth, the isolates were centrifuged and cell-free supernatants were used for IAA determination. To the $10 \mathrm{ml}$ of supernatant, $2 \mathrm{ml}$ of Salkowski reagent $(2 \mathrm{ml}$ of $0.2 \mathrm{M}$ Ferric chloride, $49 \mathrm{ml}$ of Perchloric acid and $49 \mathrm{ml}$ of Distill water) was added and incubated for 10 minutes. The blank was prepared using sterile broth with Salkowski reagent. Then the samples were checked for absorbance at 530nm. IAA standard graph curves were calibrated using Indole acetic acid (Himedia) in TSB broth at different concentration $(5,10,20,50$ and $100 \mu \mathrm{g} / \mathrm{ml})$ and sample IAA concentration was calculated.

\section{Estimation of $\mathrm{GA}_{3}$ production at different PEG 6000 concentration}

The $24 \mathrm{~h}$ old bacterial culture was taken and inoculated in $15 \mathrm{ml}$ test tubes containing sterile TSB broth without and with different PEG concentration(-0.15 MPa, -0.49 MPa and $-0.73 \mathrm{MPa}$ )in triplicate. Gibberellic acid was estimated using potassium ferrocyanide precipitation method (Holbrook et al., 1961). The cultures were incubated at $30^{\circ} \mathrm{C}$ in a shaker (180 rpm) for 7 days. After incubation, the cultures were centrifuged at $10,000 \mathrm{rpm}$ for 10 mins. To the $15 \mathrm{ml}$ of samples, $2 \mathrm{ml}$ of zinc acetate was added and after two minutes $2 \mathrm{ml}$ of potassium ferrocyanide was added and allowed to precipitate. The samples were centrifuged at 8,000 rpm for $10 \mathrm{mins}, 5 \mathrm{ml}$ of each supernatant was taken and added to $5 \mathrm{ml}$ of $1 \mathrm{~N} \mathrm{HCl}$. Then the samples were incubated at $25^{\circ} \mathrm{C}$ for 75 mins. The sterile broth with $1 \mathrm{~N}$ $\mathrm{HCl}$ was taken as blank. Absorbance was taken at $254 \mathrm{~nm}$ in UV-Vis spectrophotometer. $\mathrm{GA}_{3}$ concentration in samples was calculated the standard curve graph prepared using gibberellic acid (Himedia) in sterile TSB broth $(0.2,0.4,0.6$, 0.8 and $1.0 \mathrm{mg} / \mathrm{ml}$ ).

\section{Statistical analysis}

All the experiments were carried out with replication $(n=3)$. The mean data obtained were analyzed by one-way analysis of variance (ANOVA) and ranked using Duncan's multiple range test, correlation coefficient squared was calculated using $\mathrm{R}$ programming. Least significant difference was considered at $\mathrm{p}<0.05$ for comparing difference means of treatments.

\section{Results and Discussion}

\section{Bacterial population in rice phylloplane}

Leaf imprint technique was implemented to isolate rice phylloplane bacteria. Among four varieties Anna $R(4)$ constitutes the highest bacterial population followed by Nootripattu, PMK3 and Mattaikar (Table 1). The highest population obtained when compared to medium used was TSB medium. Hence all the 
bacterial isolates from different media were purified in TSB medium.

\section{Screening of abiotic stress tolerant bacteria}

The isolates subjected to drought stresses were checked for OD at $600 \mathrm{~nm}$. Among the different osmotic stresses, all the bacteria attain maximum growth at $-0.49 \mathrm{MPa}$ stress.

Hence the OD of isolates above 0.5 under all abiotic stress except at $-1.2 \mathrm{MPa}$ was noted since the growth was below 0.5 OD comparatively. A total of 8 isolates were screened down, they are PB3, PB17, PB18, P23, PB24, PB37, PB46 and PB50. Isolate PB18 was noted with prominent growth under drought stress at $-1.2 \mathrm{MPa}$, whereas $\mathrm{PB} 3$ was said to be best temperature stress tolerance and PB18 and PB23 has the highest growth under salt stress (Table 2). Screened isolates were further characterized using biochemical test.

\section{Biochemical characterization}

The results from the biochemical characterization were represented in (Table 3) and the diversity analysis using biochemical characters was represented in (Figure 1). Diversity analysis shows that isolates PB46, PB50, PB3 and PB37 classified under separate clade, among them PB50 and PB46 shows close relation. Another separate clade with isolates PB17, PB18 and PB23 shows they common ancestor. The isolate PB24 remains as out group.

Table.1 Bacterial population on rice Phylloplane

\begin{tabular}{|c|c|c|c|c|}
\hline & \multicolumn{4}{|c|}{ Population (cfu/sq.cm) } \\
\hline Rice varieties & NA media & TSB media & King's B media & R2A media \\
\hline Anna R (4) & $11.13(0.98)^{\mathrm{a}}$ & $11.2(0.6)^{\mathrm{a}}$ & $10.13(0.90)^{\mathrm{a}}$ & $10(0.72)^{\mathrm{a}}$ \\
\hline PMK3 & $10.66(1.47)^{\mathrm{b}}$ & $10.26(1.52)^{\mathrm{d}}$ & $9.733(0.76)^{\mathrm{b}}$ & $9.86(0.64)^{\mathrm{a}}$ \\
\hline Nootripattu & $11.33(0.80)^{\mathrm{a}}$ & $10.8(1.21)^{\mathrm{b}}$ & $9.533(0.46)^{\mathrm{b}}$ & $9.13(0.61)^{\mathrm{b}}$ \\
\hline Mattaikar & $9.4(1.05)^{\mathrm{c}}$ & $10.53(0.92)^{\mathrm{c}}$ & $9.066(0.83)^{\mathrm{c}}$ & $8.8(0.4)^{\mathrm{c}}$ \\
\hline
\end{tabular}

Note: The numerical values are mean and SD of different observations; Same values in superscript indicates no significant difference between observations.

Table.2 Growth of isolates under different abiotic stress

\begin{tabular}{|c|c|c|c|}
\hline Isolates & PEG6000 (-1.2MPa) & NaCl (1.2M) & ${\left.\text { Temperature } \mathbf{( 5 0}^{\mathbf{0}} \mathbf{C}\right)}$ \\
\hline PB3 & $0.167(0.003)^{\mathrm{e}}$ & $1.011(0.037)^{\mathrm{a}}$ & $0.673(0.011)^{\mathrm{b}}$ \\
\hline PB17 & $0.128(0.005)^{\mathrm{f}}$ & $0.853(0.034)^{\mathrm{f}}$ & $0.459(0.007)^{\mathrm{a}}$ \\
\hline PB18 & $0.327(0.017)^{\mathrm{a}}$ & $0.846(0.007)^{\mathrm{b}}$ & $0.772(0.009)^{\mathrm{a}}$ \\
\hline PB23 & $0.293(0.004)^{\mathrm{b}}$ & $0.683(0.0043)^{\mathrm{b}}$ & $0.788(0.005)^{\mathrm{a}}$ \\
\hline PB24 & $0.122(0.006)^{\mathrm{f}}$ & $0.638(0.0036)^{\mathrm{e}}$ & $0.541(0.007)^{\mathrm{d}}$ \\
\hline PB37 & $0.157(0.006)^{\mathrm{e}}$ & $0.529(0.014)^{\mathrm{e}}$ & $0.567(0.010)^{\mathrm{c}}$ \\
\hline PB46 & $0.185(0.004)^{\mathrm{d}}$ & $0.604(0.004)^{\mathrm{c}}$ & $0.580(0.009)^{\mathrm{c}}$ \\
\hline PB50 & $0.236(0.002)^{\mathrm{c}}$ & $0.585(0.006)^{\mathrm{d}}$ & $0.547(0.023)^{\mathrm{d}}$ \\
\hline
\end{tabular}

Note: The numerical values are mean and SD of different observations; Same values in superscript indicates no significant difference between observation. 
Table.3 Biochemical characterization of drought tolerant bacteria

\begin{tabular}{|c|c|c|c|c|c|c|c|c|}
\hline & PB3 & PB17 & PB18 & PB23 & PB24 & PB37 & PB46 & PB50 \\
\hline Indole test & - & - & - & - & - & - & - & - \\
\hline MR & + & + & + & + & - & + & + & + \\
\hline VP & - & + & + & + & - & - & - & + \\
\hline Citrate utilization & + & - & - & - & - & + & + & + \\
\hline Amylase test & - & + & + & - & - & + & + & - \\
\hline Pectinase test & - & - & - & - & - & + & + & - \\
\hline Cellulase test & - & - & - & - & + & + & + & + \\
\hline Urease test & + & - & - & - & - & + & + & + \\
\hline Catalse test & + & + & + & + & + & + & + & + \\
\hline H2S test & - & - & - & - & - & - & - & - \\
\hline Gram Stain & $\begin{array}{c}\text { Gram } \\
\text { Positive }\end{array}$ & $\begin{array}{c}\text { Gram } \\
\text { Positive }\end{array}$ & $\begin{array}{c}\text { Gram } \\
\text { Positive }\end{array}$ & $\begin{array}{c}\text { Gram } \\
\text { Positive }\end{array}$ & $\begin{array}{c}\text { Gram } \\
\text { Positive }\end{array}$ & $\begin{array}{c}\text { Gram } \\
\text { Positive }\end{array}$ & $\begin{array}{c}\text { Gram } \\
\text { Positive }\end{array}$ & $\begin{array}{c}\text { Gram } \\
\text { Positive }\end{array}$ \\
\hline KOH test & $\begin{array}{c}\text { Gram } \\
\text { Positive }\end{array}$ & $\begin{array}{c}\text { Gram } \\
\text { Positive }\end{array}$ & $\begin{array}{c}\text { Gram } \\
\text { Positive }\end{array}$ & $\begin{array}{c}\text { Gram } \\
\text { Positive }\end{array}$ & $\begin{array}{c}\text { Gram } \\
\text { Positive }\end{array}$ & $\begin{array}{c}\text { Gram } \\
\text { Positive }\end{array}$ & $\begin{array}{c}\text { Gram } \\
\text { Positive }\end{array}$ & $\begin{array}{c}\text { Gram } \\
\text { Positive }\end{array}$ \\
\hline Shape & Rod & Rod & Rod & Rod & Coccus & Rod & Rod & Rod \\
\hline \multicolumn{9}{|l|}{ Carbon assimilation: } \\
\hline Glucose & + & + & + & + & + & + & + & + \\
\hline fructose & + & + & + & + & + & + & + & + \\
\hline Sucrose & + & - & + & + & - & - & + & + \\
\hline Mannitol & + & + & + & + & - & - & + & + \\
\hline Lactose & - & - & + & - & - & - & - & - \\
\hline Trehalose & - & - & + & + & + & + & + & + \\
\hline Succinic acid & + & - & - & - & - & + & + & + \\
\hline Malic acid & + & - & - & + & + & + & + & + \\
\hline Oxalic acid & - & - & - & - & - & - & - & - \\
\hline Methanol & - & - & + & - & - & - & + & + \\
\hline
\end{tabular}

Note: + and - sign in above table indicates positive and negative for the biochemical test.

Fig.1 Dendrogram using the biochemical characterization of drought tolerant bacterial isolates

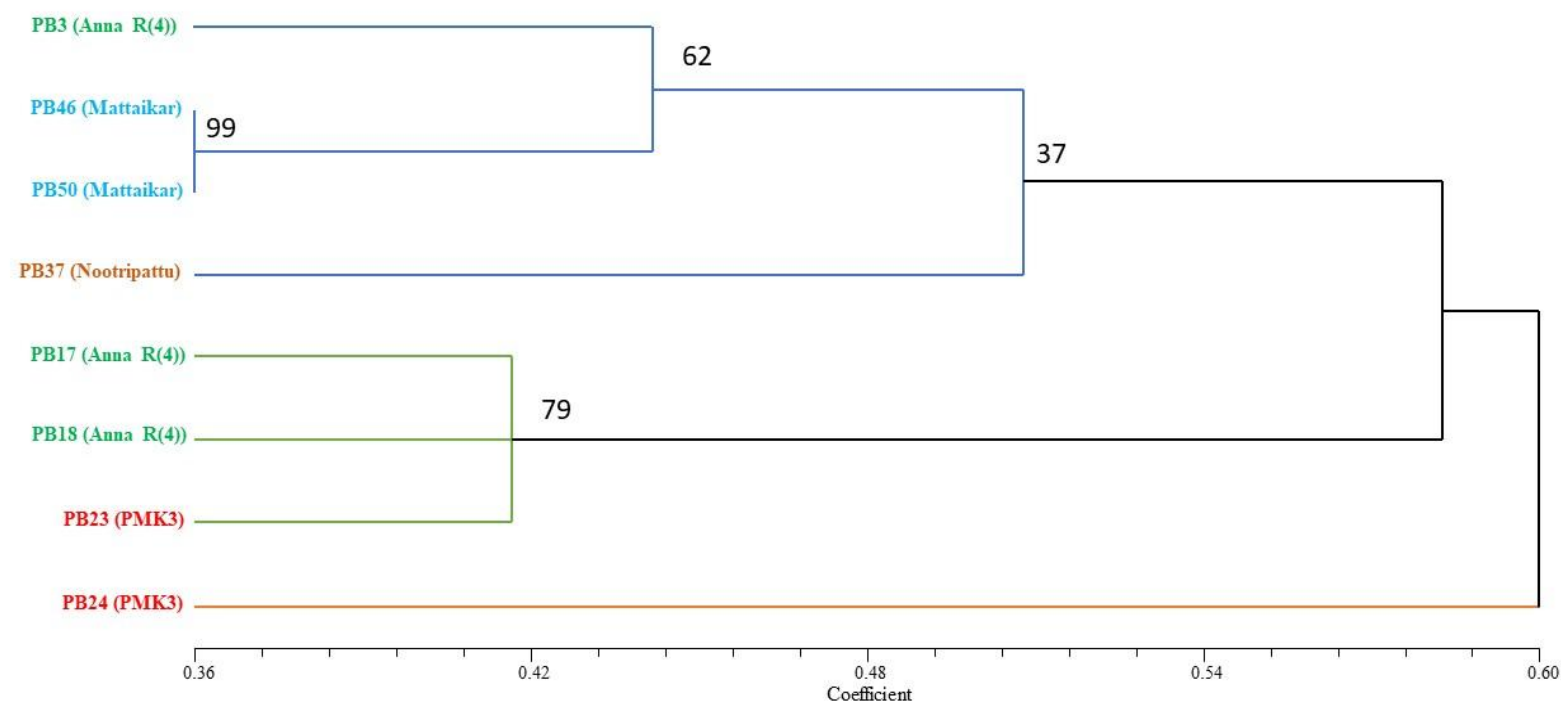


Fig.2 (A) IAA production (B) Gibberellic acid production by drought tolerant bacterial isolates

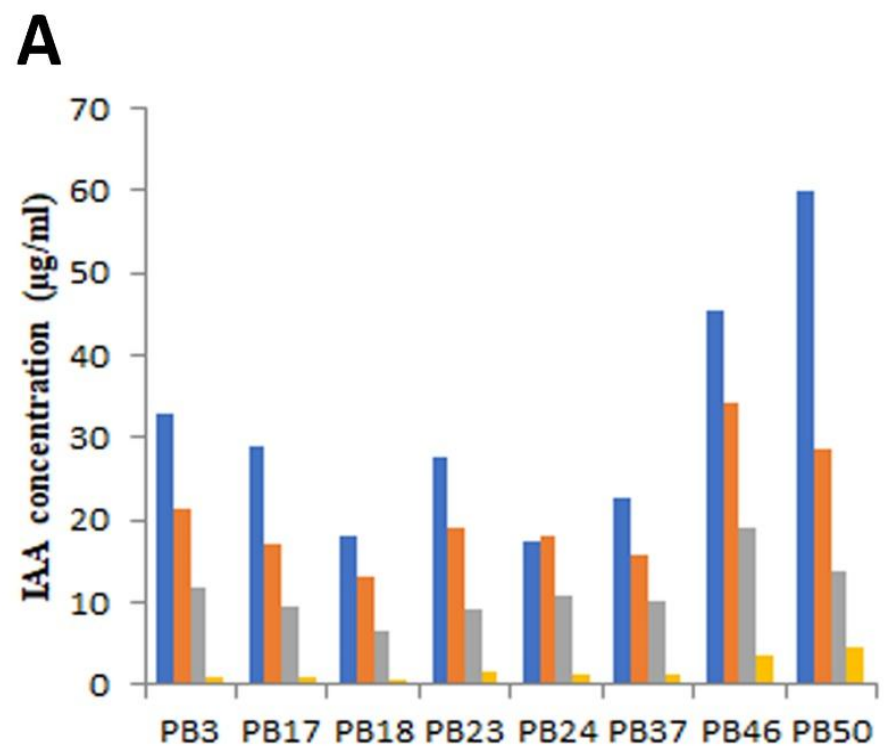

Non-stressed

घPE $6000(-0.15 \mathrm{MPa})$

घPE $6000(-0.49 \mathrm{MPa})$

I PEG $6000(-0.73 \mathrm{MPa})$

Drought tolerant bacterial isolates

B

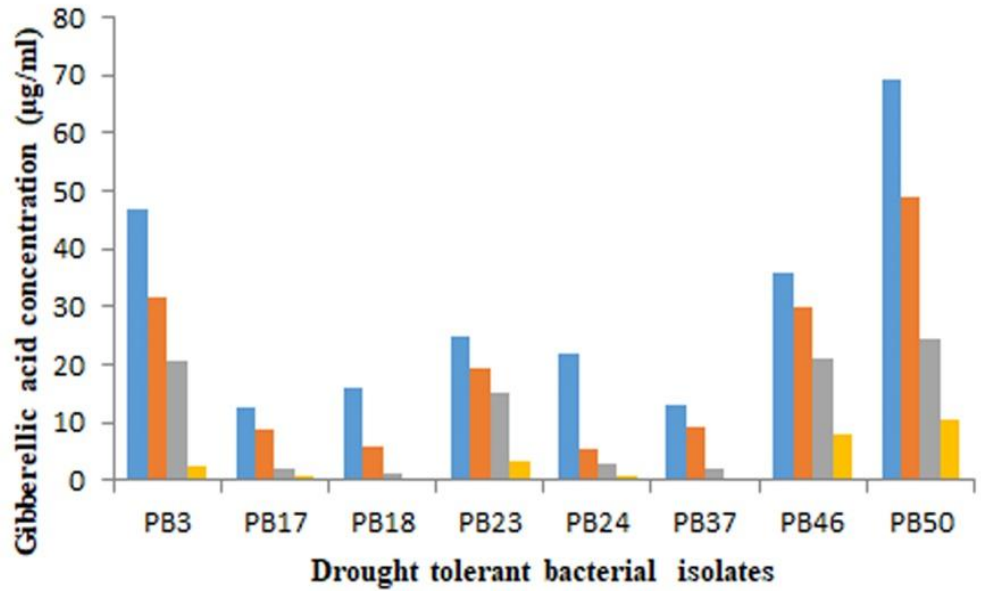

Non-stressed

a PEG 6000 (-0.15 MPa)

밈 PEG 6000 (-0.49 MPa)

InEG $6000(-0.73 \mathrm{MPa})$ 


\section{Phytohormone production}

Drought tolerant bacterial isolates were assessed for the production of phytohormones IAA and gibberellic acid. The isolate PB50 was recorded with the highest production of IAA, $60 \mu \mathrm{g} / \mathrm{ml}$ under non-stress condition and $4.72 \mu \mathrm{g} / \mathrm{ml}$ under -0.73 osmotic stress conditions. Followed PB50, PB46 has the highest IAA production and production by other isolates has no significant difference (Figure 2A). In case of gibberellic acid production, isolate PB50 produces $69 \mu \mathrm{g} / \mathrm{ml}$ under non-stress condition and $10.3 \mu \mathrm{g} / \mathrm{ml}$ under $-0.73 \mathrm{MPa}$ osmotic stress condition. Followed by PB50, the isolates PB3 and PB 46 have the highest production of gibberellic acid (Figure 2B). In both the cases, all the isolates were recorded with gradual decrease in phytohormone production with increase in osmotic stress.

Bacteria on phylloplane constantly exposed to different stress factors and could sustain in that environment. A drought tolerant bacterium with PGP traits could help the plants from drought mitigation. In present study a total of 50 bacterial isolates were obtained, among them 8 isolates are identified to grow well under abiotic stress condition. The isolates may undergo cellular mechanism of osmotic adaptation through compatible solute and osmolyte productions (Madkour et al., 1990). From the biochemical characterization and diversity analysis, it is shown that all the isolates except PB24, belongs to Bacillus species. The ability of Bacillus to produce endospore under extreme condition made them to thrive on rice phylloplane under drought condition (Nicholson et al., 2000). The bacterial isolates from individual rice varieties are closely related and it shows diversified drought tolerant bacterial isolates were present on each rice varieties. Phylloplaneis said to be highly variable environment, the bacterial population size and species varies within the plants of same species and within the same area (Hirano and Upper, 2000). All the drought tolerant bacteria isolated from rhizosphere of soybean (Glycine max) was reported to Bacillus sp. and has noted with IAA production and Exopolysaccharide production capability (Susilowati et al., 2018). Similarly, drought tolerant Bacillus sp. from maize shows plant growth promotion and reported to accumulate proline and sugars under drought condition, thus supports the growth of maize under drought stress (Vardharajula et al., 2011). The isolates PB46 and PB50 was recorded to produce high IAA and gibberellic acid production and ability to withstand under abiotic stress condition.

\section{Acknowledgments}

The authors thank the Department of Biotechnology (Foldscope), Government of India for financial support under the scheme Project "Exploring the interaction of Phyllosphere microbiome on stomatal complex through foldscope analysis for drought mitigation in rice."

\section{References}

Bringel, F., and Couée, I. (2015). Pivotal roles of phyllosphere microorganisms at the interface between plant functioning and atmospheric trace gas dynamics (Vol. 6).

Caldas, T., Demont-Caulet, N., Ghazi, A., and Richarme, G. (1999). Thermoprotection by glycine betaine and choline. Microbiology, 145(9), 2543-2548.

Fitzsimmons, L. F., Hampel, K. J., and Wargo, M. J. (2012). Cellular Choline and Glycine Betaine Pools Impact Osmoprotection and Phospholipase C Production in \&lt;span class=\&quot;named-content genusspecies\&quot; $\quad$ id=\&quot;named- 
content-1\&quot;\&gt;Pseudomonas aeruginosa\&lt;/span\&gt. $J$ Bacteriol, 194(17), 4718. doi:10.1128/JB.0059612

H. Andrews, J., and F. Harris, R. (2000). The Ecology and Biogeography of Microorganisms on Plant Surfaces (Vol. 38).

Hirano, S. S., and Upper, C. D. (2000). Bacteria in the Leaf Ecosystem with Emphasis onPseudomonas syringae - a Pathogen, Ice Nucleus, and Epiphyte. Microbiol. Mol. Biol. Rev., 64(3), 624653.

Holbrook, A. A., Edge, W. J. W., and Bailey, F. (1961). Spectrophotometric Method for Determination of Gibberellic Acid GIBBERELLINS (Vol. 28, pp. 159167): American Chemical Society.

Hossain, M. (2014). Drought Stress: A Major Environmental Constraints in Agriculture (Vol. 1).

Liang, X., Zhang, L., Natarajan, S. K., and Becker, D. F. (2013). Proline mechanisms of stress survival. Antioxidants and redox signaling, 19(9), 998-1011. doi:10.1089/ars.2012.5074

Madkour, M. A., Smith, L. T., and Smith, G. M. (1990). Preferential osmolyte accumulation: a mechanism of osmotic stress adaptation in diazotrophic bacteria. Appl. Environ. Microbiol., 56(9), 2876-2881.

Michel, B. E., and Kaufmann, M. R. (1973). The osmotic potential of polyethylene glycol 6000. Plant physiology, 51(5), 914-916.

Nicholson, W. L., Munakata, N., Horneck, G., Melosh, H. J., and Setlow, P. (2000). Resistance of Bacillus endospores to extreme terrestrial and extraterrestrial environments. Microbiology and molecular biology reviews: MMBR, 64(3), 548-572. doi:10.1128/mmbr.64.3.548-572.2000
Praveen Kumar, G., Mir Hassan Ahmed, S. K., Desai, S., Leo Daniel Amalraj, E., and Rasul, A. (2014). In Vitro Screening for Abiotic Stress Tolerance in Potent Biocontrol and Plant Growth Promoting Strains of Pseudomonas and Bacillus spp. Int J Bacteriol, 2014, 195946. doi:10.1155/2014/195946

Rahman, A., Sitepu, I. R., Tang, S.-Y., and Hashidoko, Y. (2010). Salkowski's reagent test as a primary screening index for functionalities of rhizobacteria isolated from wild dipterocarp saplings growing naturally on medium-strongly acidic tropical peat soil. Bioscience, biotechnology, and biochemistry, 74(11), 2202-2208.

Rohlf, F. (1988). NTSYS-pc - Numerical Taxonomy and Multivariate Analysis System (Vol. 2.1).

Slama, I., Abdelly, C., Bouchereau, A., Flowers, T., and Savouré, A. (2015). Diversity, distribution and roles of osmoprotective compounds accumulated in halophytes under abiotic stress. Annals of botany, 115(3), 433447. doi:10.1093/aob/mcu239

Sugiura, M., and Kisumi, M. (1985). Osmoregulation in a proline-producing strain of Serratia marcescens. Microbiology, 131(10), 2515-2520.

Susilowati, A., Puspita, A., and Yunus, A. (2018). Drought resistant of bacteria producing exopolysaccharide and IAA in rhizosphere of soybean plant (Glycine max) in Wonogiri Regency Central Java Indonesia. Paper presented at the IOP Conference Series: Earth and Environmental Science.

Thayer, D., and Murray, J. O. (1977). Physiological, biochemical and morphological characteristics of mesquite wood-digesting bacteria. Microbiology, 101(1), 71-77.

Trivedi, P., Schenk, P. M., Wallenstein, M. D., and Singh, B. K. (2017). Tiny 
Microbes, Big Yields: enhancing food crop production with biological solutions. Microbial biotechnology, 10(5), 999-1003. doi:10.1111/17517915.12804

Vardharajula, S., Zulfikar Ali, S., Grover, M., Reddy, G., and Bandi, V. (2011). Drought-tolerant plant growth promoting Bacillus spp.: effect on growth, osmolytes, and antioxidant status of maize under drought stress. Journal of Plant Interactions, 6(1), 114. doi:10.1080/17429145.2010.535178

Yadav, R. K., Yadav, P., Karamanoli, K., and Vokou, D. (2010). ESTIMATING BACTERIAL POPULATION ON THE PHYLLOSPHERE BY SERIAL DILUTION PLATING AND LEAF IMPRINT METHODS (Vol. 17).

\section{How to cite this article:}

Arun Kumar, D., K.G. Sabarinathan, R. Kannan, D. Balachandar and Gomathy, M. 2019. Isolation and Characterization of Drought Tolerant Bacteria from Rice Phyllosphere. Int.J.Curr.Microbiol.App.Sci. 8(06): 2655-2664. doi: https://doi.org/10.20546/ijcmas.2019.806.319 